\title{
ARTICLE
}

\section{Towards New Literacies and Social Justice for Engineering Education}

\author{
Wendy Cumming-Potvin, ${ }^{*}$ John Currie ${ }^{+}$ \\ * School of Education, Murdoch University, w.cumming-potvin@murdoch.edu.au \\ † Faculty of Engineering, University of Sydney, john.currie@sydney.edu.au
}

This paper argues for the need to develop engineering students with high levels of technical competency as well as critical awareness for the realities of working and living ethically in the global community. Drawing on social constructivist principles of learning (Vygotsky, 1978) and a pedagogy of multiliteracies (New London Group, 1996, 2000), the paper explores new approaches for engineering education to meet the challenges embedded in current undergraduate programs and professional accreditation standards. To improve the ability of engineers to contribute to social and environmental justice, there needs to be a rethinking of engineering curriculum and pedagogy to develop engineering literacies that encompass a social and technical focus.

KEYWORDS: engineering education, social justice, multiliteracies

\section{INTRODUCTION}

Underpinned by technology and science, the discipline of engineering has traditionally been recognized as a profession and industry contributing to economic development and prosperity of nations. Recently however, engineering has been alternatively defined as more than the mathematical and scientific resolution of problems, thus embracing innovation and concern for human welfare (National Academy of Engineering, 2008). This revised positioning of engineering acknowledges that with prosperity often come negative impacts of technological advancement, such as pollution, climate change and displacement of local communities. Applying scientific knowledge has enabled understanding of the world and domestication of landscapes, resulting in increased commerce, goods and food supplies. Still, unanticipated changes in ecosystems suggest that future scientific applications should domesticate nature more judiciously to balance tradeoffs between ecosystems and provision of other services (Kareiva, Watts, McDonald, \& Boucher, 2007).

While the technical focus of traditional engineering education has achieved strong competence among graduates, the development of a corresponding level of knowledge about the broader socioeconomic and environmental impacts of the engineering endeavour has been limited (Apelian, 2012; King, 2008). Although some curriculum innovation in engineering has been noted, a popular approach to overcome the gap between technical and broader social aspects of student competency has been to incorporate additional stand-alone subjects into dense course content (King, 2008). Such subjects equip students with a broad, but relatively shallow understanding of the internal organisational and external societal consequences of industrial practice.

Recent debates in engineering education have focused on how narrow or broad a professional degree should be, and how much content should be inspired from a humanities curriculum (Riley, 2008). For Riley, an emerging approach to engineering education integrates concepts from the humanities, such as ethics or critical and reflective thought. These discussions have highlighted the 
need for engineering education to develop technically competent graduate engineers, who increasingly consider the diverse social and cultural needs of communities. Bourn and Neal (2008), for example, argue that higher education must shape engineering solutions to match social, economic, political and cultural landscapes and the impact that local action has on global communities.

The aim of this paper is to contribute to the discussion of developing professional engineers who seek social justice through critical thinking and reflective action. We argue that this discussion is beneficial to reformulate engineering education and practice to solve major societal problems using technology in a humane and ethical manner. This shift for engineering is necessary in response to society's progressively more complex technical issues, which are linked to recent community concerns over issues such as sustainability, poverty and education (Cumming-Potvin, Baillie, \& Bowden, in press). The present paper defines the concept of social justice prior to reviewing the development of engineering education and proposed reforms from professional bodies. Drawing from theory in the humanities, the paper turns its attention to the broadened notion of literacy and how it relates to engineering education. Proposing new literacies for social justice, the paper presents a pedagogy of multiliteracies (New London Group, 1996, 2000). Using empirical studies from the fields of scientific literacies and mechanical engineering, recommendations relating to the multiliteracies aspects of critical framing and transformed practice are highlighted. To deepen the critical and transformative aspects of multiliteracies for the field of engineering education, liberative pedagogy (Freire, 1970, 2005) is integrated with a pedagogy of multiliteracies, suggesting an emerging model for educating reflective and critical engineers.

\section{Defining SOCIAL JUSTICE: LINKS to ENGINEERING EdUCATION}

According to Adams, Bell and Griffin (2007), social justice is an essential educational goal, aiming for learners to understand social differences and oppression in personal lives and at the societal level. However, Rountree and Pomeroy (2010) argue that the term is fraught with contested definitions. Popular since the industrial revolution, the term social justice is often used to debate the relationship between ruling classes and the new urban poor (Cooper \& McKenna, 2008; Garland, Massoumi, \& Ruble, 2007; Novak, 2000). Social justice commonly refers to the manifestation of human rights in the everyday lives of individuals at all levels of society (Edmund Rice Centre, 2000). Thus, social justice is linked to environmental justice, which is commonly defined as the fair treatment and meaningful engagement of all individuals, (notwithstanding race, national origin or income), for developing and implementing environmental laws and policies (U.S. Environmental Protection Agency, 2011).

Paavola and Adger (2006) describe two broad approaches to justice. The first, or cosmopolitan approach, views justice as universal or unchanged by time and place. The second, communitarian, considers justice to emerge from relationships between members of communities, which are specific to a particular time and place (Bell, 1993). One advantage of the communitarian approach, argue Paavola and Adger, is that it facilitates our understanding of the diverse ways in which justice is addressed in communities. However, the communitarian approach has been criticized due to multiple interpretations of the term community. For example, the community for environmental justice has often been described as all human beings who will be affected by global climate policy and practices.

Riley (2008) describes social justice as a familiar and elusive term in relation to engineering education; social justice is linked to normative perceptions of truth and fairness and how these concepts should be applied in society. Reminiscent of the work of Riley, the present paper suggests 
that for engineering, it is important to consider the differences between distributive and procedural justice. Distributive justice points to benefits and costs, broadly encompassing financial profits and burdens (Kolm, 1996). Procedural justice includes the way in which parties are positioned for planning and decision-making and issues such as participation, recognition and distribution of power (Fraser, 2001; Paavola \& Adger, 2006; Young, 2000). Paavola and Adger note that distributive and procedural justice are interrelated; if a group cannot participate in planning and decision-making, its interests are unlikely to inform social, political or financial actions, which can aggravate, rather than reduce inequality. Therefore, the present paper argues for a holistic perspective which considers multiple aspects of social justice for engineering, such as oppression, exploitation, marginalization, powerlessness and cultural imperialism. In light of Young's (2000) diverse aspects, we define social justice by drawing on Riley (2008), who suggests that social justice is ever-changing and:

- grounded in context, place and time;

- developed on both individual and community levels;

- intended to achieve equality and respect the human rights of all people;

- embedded in balancing the relationship between human kind, the environment and animals.

While communities have benefited greatly from engineering, its impacts may increase the gap between social classes and damage the world's environmental health. As these trends amplify in capitalist societies, we argue that it is compelling to contemplate a new approach to engineering education-both in curriculum and pedagogy. This emerging approach to engineering calls for a profession that serves humanity in pursuit of social justice, rather than serving an increasingly corporate culture, driven predominantly by profit (Baillie, 2006; Riley, 2008). Baillie and Catalano (2009) argue that to promote fairness and social justice, engineering students must develop complex insights to respond appropriately to communities while acknowledging that the profession can influence societies' lifestyles and ecosystems. In describing issues of justice, we contend that engineering must account for procedural justice linked to design, technical knowledge, benefits and costs; but engineering must also consider complexity of human experiences and distribution of power. In this vein, distributive justice must be connected to the raison d'être of engineering.

\section{Development of Engineering Education: Positivism, Specialisation, PROFESSIONALISM AND REFORM}

With a desire to improve technology and use it effectively in society, engineering education has its origins in a positivist approach to science (Jawitz \& Case, 2009). The positivist approach defines scientific activity as objective and focussed on solving technical problems (Pool, 2003). Preceded by artistry and skilled trades of the Renaissance, (Singer, Williams, \& Raper, 1954-84), engineering approaches of the Industrial Revolution began to seek systematic explanations to practical problems. By the nineteenth century, trial and error experimentation was gradually replaced with an academic program aiming for strong theoretical grounding in sciences and mathematics. Emphasis on the mathematical and scientific specialisation of engineering continued through the twentieth century (Wankat, Felder, Smith \& Oreovicz, 2002). Combined with mathematical and scientific theory, this perspective of technical expertise saw the American Engineering profession develop broadly in two ways: one which tied engineers intricately to business and one which encouraged autonomy (Layton, 1971). Denouncing industrial waste and working conditions in the engineering profession, the progressive movement, argued Layton, peaked after World War I. Since then, engineering has often been linked to dilemmas of social justice created by competing factors, 
such as technical specialization, professional autonomy, accountability to employers and social responsibility.

Since the Second World War, technical specialisation has increased via numerous sub-disciplines of core engineering areas, such as Mechanical, Civil, Chemical, Electrical and Mining. While specialisation has resulted in spectacular expansion of technical knowledge, the impact for engineering education has been a dense technical curriculum, which is often disjointed from issues of social justice. Emphasis on theoretical knowledge has also been accentuated by an academic culture that understands its core endeavours as research and teaching. Of these core functions, the development of new technical knowledge through research is often more rewarding to academics who may have few career incentives for pedagogical innovation. This has reached the point where many undergraduate engineering students experience much of their programs as a series of disconnected theoretical subjects with high levels of contact hours, study load and examinations, which are segregated from social and environmental realities.

Recent research suggests that despite curriculum reform in some engineering schools to deliver a broader range of graduate attributes, more work is needed to examine this cultural shift from a systemic and holistic perspective (King, 2008). If social justice is to flourish in engineering, developing a profound sense of ethical responsibility is necessary. Baillie and Catalano described such an ethical position as morally deep, where professional fulfilment "holds paramount the safety, health and welfare of identified integral communities" (2009, p. 169). Inspired by the work of Baillie and Catalano, which demonstrates the gap between ethical rhetoric and the engineering education reality, we argue for a thorough consideration of engineering ethics. From this viewpoint, there is concern that a technically driven curriculum may link ethics with environmental and social justice merely at the descriptive level of tutorial activities for industrial management or professional engineering subjects.

With codes of conduct and accreditation processes, professional engineering associations are influential in guiding contemporary higher education direction. For public recognition of graduates and recruitment of students, engineering faculties require acceptance by professional accreditation bodies. The Australian professional association, Engineers Australia offers graduates direct membership in turn for the right to accredit degree programs. Accreditation is based upon Stage 1 Competency Standards that outline general requirements for the graduate Knowledge Base, Engineering Ability and Professional Attributes. The competencies are listed with specific Engineering Ability and Professional Attributes (Engineers Australia, 2010). These competencies acknowledge the importance of educational areas related to engineering and social justice, such as "understanding of social, cultural, global and environmental responsibilities and the need to employ principles of sustainable development" (PE 2.2), "understanding of professional and ethical responsibilities and commitment to them" (PE 3.4) and "general knowledge" (PE 1.4). However, a majority of competencies emphasise the demonstrable acquisition of technical knowledge and skills (PE 1.1-1.3, 2.1, 2.3-2.6). Despite engineers' social responsibility to "optimise social, environmental and economic outcomes" (Engineers Australia, 2010, p. 1), the role of the engineer is generally described as technical. In this point, the professional association recognises the need for engineers to play a broader social and environmental role. Yet the emphasis on technical competencies sends a powerful message to engineering educators, highlighting the primacy of technical knowledge in a crowded curriculum.

This conundrum is inherent in the report for the Australian Council of Engineering Deans where this educational heritage of engineering is overlaid with a desire for curriculum reform to better serve the needs of society (King, 2008). King praised initiatives in curriculum inclusivity and multi- 
disciplinarity to advance the understanding of environmental and social justice in engineering. The King report acknowledges the international interest in changing engineering education, which is reflected in the Michigan Millennium project (Duderstadt, 2008) and the Carnegie foundation reports (Sheppard, Mactangay, Colby, \& Sullivan, 2008). The Report also calls for curriculum development positioned around problem solving, application and practice to address contemporary social and environmental issues (King, 2008, p. 107-109). Unfortunately, models and/or action strategies to advance such calls are absent beyond the dissemination of identified good practice.

Duderstadt (2008) proposes the way forward for engineering education as increasing the professionalisation of course offerings. Students would take a more generalist under-graduate curriculum prior to engaging in post-graduate engineering experiences. The call for increased professional emphasis has historical antecedents in the Flexner report of 1910 (1972) with its desire to emulate education initiatives in medicine to enhance the standing of engineers in the USA. While such professionalisation adds potential breadth to engineering education, we contend that it does not guarantee a re-structuring of engineering curriculum and pedagogy to profoundly engage with the complex human and global issues of environmental and social justice.

Considering the future for engineering education, The Carnegie Foundation report recommends four principles:

1) Provision of a professional "spine;"

2) Teaching key concepts for use and connection;

3) Integration of identity, knowledge and skills through approximations of practice;

4) Placing engineering in the world (Sheppard, Macatangay, Colby, \& Sullivan, 2008).

We agree that Duderstadt's (2008) principles offer the potential for students to be viewed as actively engaged professionals-in-training. However, the realisation of such principles requires engineering educators to substantially renew pedagogy and curriculum to better integrate technical considerations with the skills required of professional practice challenged by contemporary social and environmental contexts. Therefore, we suggest this stance also requires a concept of professionalism to enhance the ethical understandings and motivations of students to go beyond the commercial aspects of engineering practice.

\section{ENGINEERING AND THE HUMANITIES: LITERACY, LITERACIES AND MULTILITERACIES}

The shift towards educational reform which considers social context and individual cognition is not unique to engineering. For several decades, literacy debates in the humanities have raged over the teaching of reading and writing to children (Snyder, 2008). Heated discussions about which "basics" to teach in primary and secondary schools are drawn out in public and political arenas (Walsh, 2008). Since the 1990s, researchers have repeatedly called for expanded ways of interpreting literacy to go beyond an industrial model of schooling that ignores students' social contexts (Bomer, Zoch, David, \& Hyounjin, 2010; Luke, 2000). To emphasize that literacy practices vary across sociocultural and historical contexts, researchers have increasingly replaced the term literacy with literacies to signify more than a static set of reading and writing skills (Harran, 2006). Hence, this paper adopts a definition of literacies as complex practices, which unfold dynamically through social interaction across diverse communities. From this view point, students whose home literacies differ from schools' prescribed language and behavioural routines can be disadvantaged (see for example Cumming-Potvin, 2009; Cumming-Potvin, Renshaw \& van Kraayenoord, 2003; Martino \& Cumming-Potvin, 2011). 
In engineering education, the concept of literacy has also evolved from a focus on transmitting basic skills about reading and writing to a more student-centred approach, developing effective learning strategies. Since the 1990s, assisting engineering students to develop information literacy skills has emerged as a popular theme, especially for first year cohorts (see Feldman \& Feldman, 2000; Hill \& Woodall, 1999; Palmer \& Tucker, 2004). Some engineering educators (Messer, Kelly, \& Poirier, 2005) have highlighted a more contemporary concept of literacy that includes strands of reading, writing, speaking, listening and viewing. This approach emphasizes the breadth of literacies needed from multidisciplinary fields for engineering students to communicate critically in modern, professional and ethical contexts. More recently, Archer (2008) adopted a social-critical concept of literacies to explore how engineering students from disadvantaged backgrounds in South Africa negotiated their identities through projects involving writing about power, housing and water in rural settlements. In this instance, the social-critical approach involved a key question aiming to provide students access to dominant forms of writing and established protocols in the discipline of engineering while simultaneously validating students' literacy practices and resources.

Harran (2006) defined these contemporary concepts of literacies as extending beyond technology or a transferable set of cognitive skills. Reading, writing, speaking, listening and viewing are viewed as literacy practices evolving in individual, social and political worlds. It has also been argued that today's literacies must draw on digital environments to encompass reading and interpreting media (images, written text, sounds and movement) for designing, applying and evaluating new knowledge (Brown, Lockyer, \& Caputi, 2010; Jones-Kavalier \& Flannagan, 2006). Specifically, Brown et al. (2010) described multimodal texts as involving a range of literacies allowing students to use, communicate with and critically evaluate information from a wide variety of media forms.

To reflect the changing conceptions of leading human lives and engaging with literacy practices in private, public and personal spheres, the New London Group (1996; 2000) argued for a new pedagogy of literacy. The New London Group coined the expression multiliteracies to propose a pedagogy, which emphasizes learners' meaning-making within the multiplicity of shifting communications and rapidly changing and culturally diverse worlds. This pedagogy draws on social constructivist learning principles, (see Vygotsky, 1978), whereby the student is viewed as an active constructor of knowledge through enquiry and is scaffolded or assisted by more experienced peers and/or the teacher (see also Kemmis, Cole, \& Suggett, 2005). More particularly, multiliteracies provide a social-critical orientation to learning that encourages debate beyond pedagogy and curriculum to examine social changes, especially related to computer-mediated communication (Luke, 2000). Borsheim, Merritt and Reed (2008) confer that multiliteracies have deepened and broadened the concept of a literate person; a multiliterate person is flexible and strategic and uses literacy practices with diverse texts in socially responsible ways.

With group members from linguistics, sociology of education, cultural studies, etc., the New London Group aimed to celebrate a pluralistic society where education would promote social justice (Cole \& Pullen, 2010). Notwithstanding multiliteracies' international notoriety, Mills (2009) argued that the "how to" of the pedagogy has been received with enthusiasm and reservations, highlighting that issues of power and ideology should not be disregarded. This is fundamental as, historically, literacy has often been used as a tool to reconstruct the social order of the status quo. Still, Cole and Pullen contend that multiliteracies have been successful on many fronts, particularly in classrooms where literacy instruction has expanded beyond the dualism of reading and writing printed texts. Multiliteracies have also broadened the representation of language from simple sound-letter correspondence to include audio, visual, gestural, and spatial design. 
The New London Group (2000) acknowledge that translating a theory of pedagogy into practice is not a panache containing miracle recipes. In this vein, the authors stipulate that educational reformists must clearly state their ideological assumptions about learning. To navigate a new literacy landscape and aim for socially just learning opportunities, a pedagogy of multiliteracies assumes that human knowledge is constructed collaboratively in communities across social, cultural and material contexts (Cumming-Potvin, 2009). From initial social interactions involving diverse skills, backgrounds and perspectives, abstractions can be developed. Therefore, we could argue that the process of becoming literate informs the development of graduate engineers; whilst both processes are technical, they are highly complex and draw on social, cultural and historical factors. In this sense, a pedagogy of multiliteracies (New London Group, 2000, p. 35) is underpinned by four key components, which occur simultaneously and repeatedly in complex ways:

Situated practice:

- The learner is immersed in literacies situated in or similar to real life worlds. The use and function of situated practice draw on the knowledge of experts or novice experts.

Overt instruction:

A teacher or more experienced learner actively intervenes to scaffold students in a conscious and systematic way through design elements.

Critical Framing:

- The learner views knowledge through a critical frame and learn to "read between the lines," taking context into consideration.

Transformed Practice:

- The learner transfers or redesigns an existing practice into new contexts or cultural sites.

Acknowledging the importance of immersing all learners, including engineers and future engineers in meaningful experiences, we are inspired by the New London Group (2000) whose work called for effective pedagogy to move beyond situated practice to incorporate two critical elements: the conscious control and awareness about parts of a system and the ability to critique a system as it relates to ideology and power. From this perspective, curriculum reform is inexorably linked to contending and related fields of power, which can promote the status quo (Bourdieu, 1991). Still, for Cole and Pullen (2010), the pedagogical power of multiliteracies is found in its ability to connect young people online via changing social practices. Globally, for example, a large number of youths can now informally learn a plethora of new skills in virtual worlds involving role-play and imaginative scenarios. Moreover, Pilay (2010) suggests that embracing multiliteracies is linked to developing socially just learning environments; by celebrating students' diverse literacy practices, educators in higher education can facilitate the dismantling of "white men's clubs" ethos, which empowers the privileged. To this respect, the celebration of diversity, which is characteristic of a multiliteracies' approach, appears to be highly relevant for the discipline of engineering, which has generally been associated with training white privileged males (see Riley, 2008; Strutz, Orr, \& Ohland, 2012). 


\section{A PedAgogy Of Multiliteracies: From TheORY to ACtion}

Since its creation, the New London Group's concept of multiliteracies has evolved across many disciplines, such as geography, history, economics and science (Mills, 2009; Weinstein, 2006). To promote reflection about new literacies in engineering, Exley's (2008) science-based research provides a useful example of a pedagogy for multiliteracies in action (Kalantzis \& Cope, 2005; New London Group, 2000). Conducted in a Year 5 classroom, the Land Environments Board Game Project aimed to promote scientific literacies with students producing three-dimensional board games about land forms, such as coasts, arid interiors, wetlands and woodlands.

The strengths of Exley's (2008) project lie in situated practice and overt instruction. Successfully drawing on students' current understandings about land forms, the teacher (Olivia) used situated practice with multi-media texts to engage student interest. An excursion into the real world provided concrete examples from which students could gather data. In school, the teacher exploited board games, often considered popular cultural texts, so that students could examine and produce procedural texts. Overt instruction for student learning was scaffolded as Olivia guided explicit discussions about language. Collaboratively examining features of procedural texts while engaging in inquiry-based learning, students merged technical and conversational language. Thus, the derived sense of literacies, often referred to as being knowledgeable in science, were balanced with a fundamental sense of literacies, defined as understanding science-specific texts (see Norris \& Phillips, 2003).

Whilst critical framing was developed as students negotiated assessment criteria and evaluated board games, the critical aspect of scientific literacies could be extended by inviting students to take digital photos of land forms. To move beyond categorization, open-ended questions related to social and environmental justice could be presented. For example: How might weather impact on these land forms? How might humans change these land forms? How might industries change these land forms? Who might profit from these changes? Opportunities for students to research and design questions using print and multi-modal texts could provide extension. While Year 5 students produced board games for their classroom, to extend this transformed practice, the games could be played in diverse settings, such as another classroom, or at home. Discussions could take place about the need to design games in light of purpose and audience. For students whose families use English as an additional language, issues such as translation and cultural interpretation of texts could be broached. Extension activities might include opportunities for students to adapt their games for online settings. Reflection about the collaborative process of learning as well as an interrogation about whose voices are privileged could take place in multi-modal formats.

Whilst Exley's study was conducted with primary school students to develop basic scientific literacies, the work is clearly underpinned by a pedagogy of multiliteracies, and could promote alternative perspectives to the traditional science curriculum, which ultimately creates student pathways to higher-level courses associated with engineering (see Aikenhead, 2003). Whilst a pedagogy of multiliteracies has not yet been readily applied to tertiary education, particularly in engineering, innovative research involving teaching with online gaming in an American undergraduate engineering program, illustrates efforts of curriculum reform. Whilst their research is not formally buttressed by a pedagogy of multiliteracies, Coller (2007) and Coller and Scott (2009) used a video game based on simulated cars to re-design a core course in mechanical engineering. The authors concluded that when compared with students taking the traditional lecture/textbook-based numerical methods course, participants in the re-designed course spent approximately twice as much time outside of class on their studies. In a concept-mapping activity, 
these same students also demonstrated deeper learning when compared to their counterparts taking the traditional course.

The multiliteracies' aspects of this research can be interpreted as situated practice and overt instruction (New London Group, 1996, 2000). Based on the constructivist principles of drawing on learners' worlds, the New London Group's situated practice resonates with using new literacies, such as the Internet and other Information and Communication Technologies; such skills are often associated with significant criteria for leading an engaged life the 21st century (International Reading Association, 2009; Leu, et al., 2011; National Council of Teachers of English, 2008). For example, video games provide opportunities for learners to be immersed in simulated worlds where they face open-ended challenges similar to professional settings (Coller \& Scott, 2009; Shaffer, 2006). In addition, Coller's (2007) and Coller and Scott's (2009) use of video games highlights the multiliteracies aspect of overt instruction in engineering methods, such as solving systems of linear algebraic equations, learning computational techniques and writing computer codes. Aligned with the work of Gee (2003), Coller and Scott argue that video games provide a series of progressively challenging tasks, embedded within design. With copious and immediate feedback built into design, discovery is encouraged in a cyclical process of hypothesis and metacognition. Consequently, scaffolding is embedded in the gaming environment to guide learners through complex problem solving and open-ended tasks. With principles such as growing mastery at graded levels, Gee argued that this environment inspired motivation by signalling the learner's on-going achievements. Therefore, the scaffolding encourages the learner to successfully operate on the outer edge of their intellectual resources .

The research of Coller (2007) and Coller and Scott (2009) demonstrates how a car racing video game can scaffold engineering students to accomplish open-ended tasks and overcome technical challenges resembling those of the professional world. Rigorous engineering problems relating to transmission, tire mechanics, suspension, etc. can be made accessible to students. However, aiming for balance in a multiliteracies framework, the aspects of critical framing and transformed practice could be extended. NIU-Torcs, the video game used by Coller and Scott resonates with commercial video games, such as Need for Speed and Gran Turismo. Generally, these types of exceptionally popular global video games promote competition between players using high levels of speed, dangerous pursuits and sports cars, associated with brands such Lamborghini, Porsche and Ferrari. Therefore, critical discussions could be raised about the social, historical and cultural factors linked to professional car racing, such as corporate sponsorship, exclusive car brands and entertainment, such as female swim suit modelling. In terms of transformed practice, when mentoring high school science students, engineering students could also design experiments to explicate the impact of speed on the seriousness of car accidents.

\section{Multiliteracies and Liberative Pedagogy: An Emerging Model for ENGINEERING EDUCATION}

Applying a pedagogy of multiliteracies (New London Group, 2000) to the work of Coller (2007) and Coller and Scott (2009) suggests new literacies to embrace the technical and social aspects of engineering education. However, to deepen the critical and transformative aspects of such engineering literacies, inspiration may be drawn from the framework of liberative pedagogy. The most celebrated writer from this movement, Freire (1970) urged educators to reflect on the dynamic relationship between teaching, learning and the construction of knowledge. An awareness of these dialectics leads to conscientização, a process of learning about sociopolitical contradictions and taking stances against oppression. Freire distinguished between traditional and alternative approaches to education. Banking education was viewed as the hierarchical transmission of 
knowledge from teacher to learner. Problem-posing education in contrast was defined as learning within a given learning community, which was negotiated through social interaction and dialogue.

For Freire (2005), the task of the teacher is to critique bureaucratization; teaching requires rigorous scientific, emotional and affective preparation. Rather than follow prescriptive methods, teachers, who are also learners, must guide their students through engagement and liberation via a range of literacy activities. Recently, numerous scholars in engineering education have reiterated the call for a shift towards liberative pedagogy, which includes social justice and the elimination of oppression based on race, gender and class (Baillie, 2006; Kabo, 2010; Riley, 2003). To enable engineering students to develop the ability to critique from a social justice perspective, this shift would need to counter many taken for granted assumptions in the profession, such as Westernstyle industrialization leads to positive outcomes for all communities of the world (Kabo, 2010).

Riley (2008) argues that praxis is a key concept for linking engineering and social justice. Praxis is regarded as a form of reflective action in which theory and practice are integrated; one does not lead the other and both are developed simultaneously, through each other (Warhust, Grundy, Laird, \& Maxwell, 2005). Referring to Freire's concept of reflective action, Riley suggests that praxis tells us much about the emergence of an engineering problem, the expertise of engineers and extent of community engagement. Praxis must also be considered in the context of ethics for engineers. Whilst Riley refers to doing the "right" thing in response to an engineering problem, Catalano (2006, pp. 1-10) offers ethical questions such as: "Who is included in engineering discussions?" "Which groups are missing from the discussion table?" "What are the global consequences?" "What are the ethical considerations?" As engineers build relationships through reflective action, communication and a commitment to communities, ethics merge with praxis (Riley, 2008). In this cyclical process, an engineer committed to social justice can therefore be viewed as reflective and critical.

Drawing on recent work incorporating liberative pedagogy in engineering education (Baillie, 20062009; Catalano, 2006; Kabo, 2010; Riley, 2003) and a pedagogy of multiliteracies (New London Group, 1996, 2000), Figure 1 below presents an emerging model for educating reflective and critical engineers. The peripheral circle of the diagram represents the holistic nature of the model, emphasizing the broad aim of social justice for engineering education. The second concentric circle represents multimodal texts, illuminating the flexibility of learners to use a range of texts, with multiple modes of representation, including digital and technological. The third concentric circle emphasizes the range of new literacy strands, such as spatial, audio, gestural, linguistic and visual, which can be used in the physical design of engineering objects or systems.

Interrelated and overlapping within the next concentric circle are the multiliteracies aspects of: situated practice, overt instruction, critical framing and transformed practice. These aspects link problem-solving to constructivist theory, through processes such as scaffolding, whereby a more experienced learner guides a less accomplished learner, or a teacher draws on life-like experiences to design learner-centred tasks. Critical framing allows the learner to ask questions such as: Whose point of view is being privileged? Whose point of view is missing? Transformed practices afford learners the opportunities to adapt their products or designs to alternative settings or audiences. At the heart of the diagram sits praxis, representing fusion between theory, reflection and action. Aiming for social justice, Freire (2005) argued that praxis involves dialogue between students and teachers and leads to concerted action for assisting local populations. 


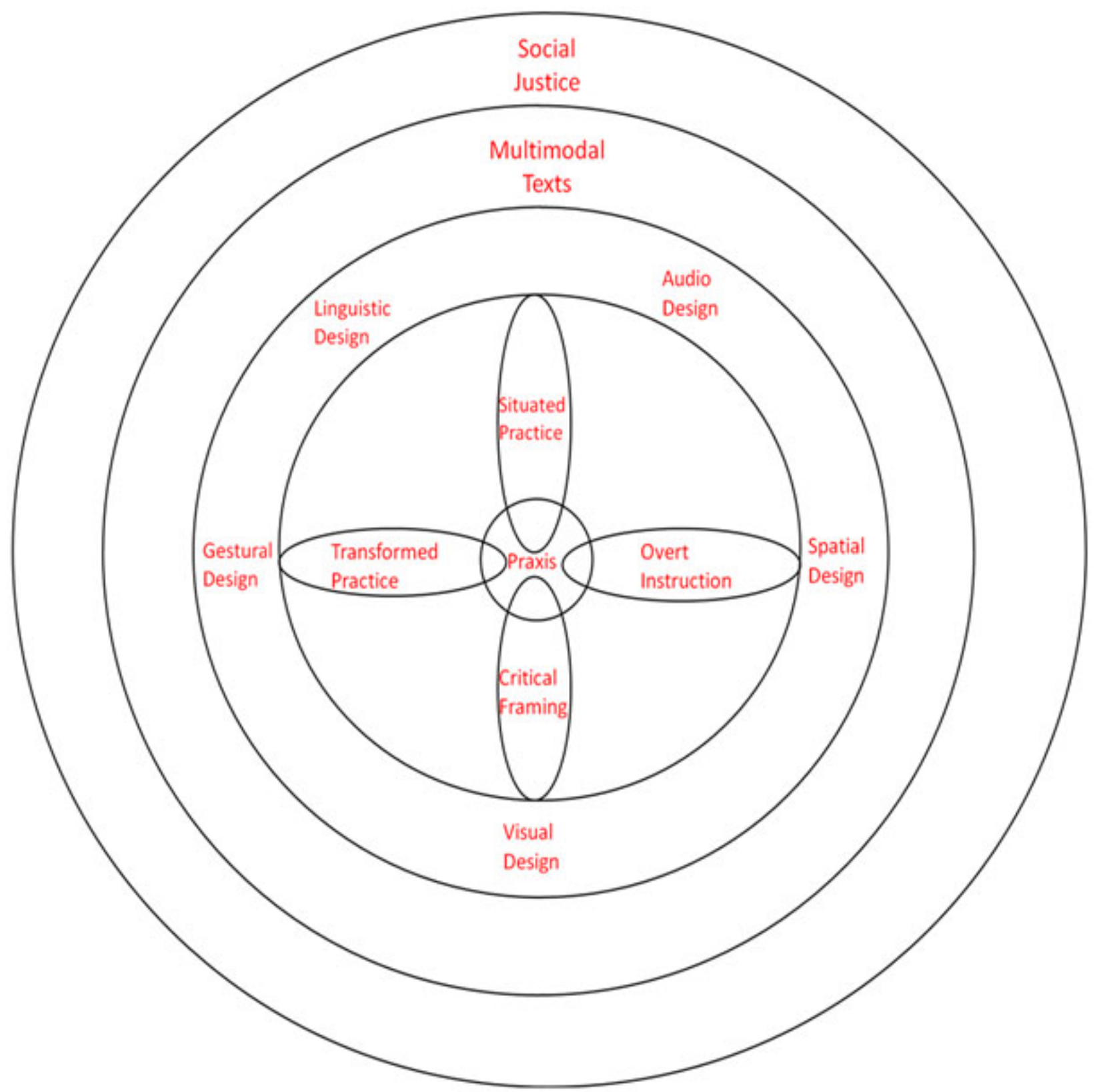

Figure 1. An Emerging Model: Multiliteracies and Liberative Pedagogy. Adapted from: Baillie, 20062009; Catalano, 2006; Freire, 1970, 2005; Kabo, 2010; Riley, 2003; New London Group, 1996, 2000.

Integrating procedural and distributive justice and a shift away from scientific positivism, the multiliteracies and liberative pedagogies model can tentatively be applied as an example to the curriculum of mining engineering. Generally, it can be argued that undergraduate mining engineering assignments accentuate the mathematical and scientific reasoning associated with the techniques of mine design and planning. For example, students are expected to conceptualize the design of stopes, which involve large-scale excavations to remove the ore (material from which mineral or metal can be profitably extracted). Students are also expected to calculate the projected tonnes to be mined from the orebody. Mining methods are justified in terms of productivity, safety and cost-effectiveness. 
If the emerging model were integrated into such technical assignments, critical practice could assist to contextualize mine design from the beginning of the mine's life to consider social issues related to exploration. The voices of multiple stakeholders could be analysed via multimodal texts and open-ended questions such as: Who owns the prospected land? Depending on location (e.g. states across Australia, developing countries, etc.), how is ownership determined? Situated practice could be incorporated via incursions or excursions whereby guest speakers introduce case studies highlighting leading practice used to manage all stages of a mine's life, including sustainable development and mine rehabilitation (Commonwealth of Australia, 2006). Overt instruction could be embedded in multimodal tasks to better understand the range of professional engineering texts required for diverse audiences and purposes. With computer-based simulated programs, various stages of a mine's life could be described, with closed and open-ended tasks used to promote students' mathematical, scientific, creative and critical reasoning. Finally, to promote reflective practice about their learning, students could be scaffolded regularly via online blogs, iPad note taking and concept maps (via software programs such as Inspiration).

A further example pertaining to civil engineering is given to illustrate how the emerging multiliteracies and liberative pedagogies model could be applied. In traffic engineering, for instance, as modern roundabouts appear with increasing frequency in North America, complex social and technical challenges unfold. Differentiated from rotaries or non-conforming traffic circles, which have been used over many years, a modern roundabout is defined as a circular road junction with a central island around which traffic moves in one direction (Roundabout, n.d.). The modern roundabout conforms to two basic design principles: yield at entry, giving right of way to vehicles in the circulatory roadway and deflection of entering traffic, due to the absence of nontangential entries and a central island, forcing lower entry speeds (Jacquemart, 1998; Rodegerdts et al., 2010). Originally developed in the UK, modern roundabouts have often been recognized as providing potential benefits such as increased traffic flow and fewer crashes compared to signalled intersections (Furtado, 2004; Inman \& Davis, 2007, Russell \& Mandavilli, 2004). On the other hand, concerns have been raised that roundabouts are not accessible to low-vision and blind pedestrians (Russell \& Mandavilli, 2004; Transportation Research Board, 2013 U.S. Access Board, 2010) and multi-lane roundabouts may actually increase safety risks for cyclists and pedestrians, especially those who may be vulnerable, such as the disabled (Arnold et al., 2010). Increasingly, traffic engineers are confronted with competing opinions from those responsible for addressing communities' traffic flow and stakeholders who are protected under the Americans with Disabilities Act (2008).

By applying the multiliteracies and liberative pedagogies model to traffic engineering studies, social aspects of selecting roundabouts could be integrated with technical design through situated practice. This process might involve engineering students liaising with shire councils to determine local policies, traffic and environmental regulations and community consultation. To complement technical aspects of design such as geometry, vehicle capacity and space feasibility, engineering students could use mobile technologies to interview targeted community members about perceptions and experiences of using roundabouts. Scaffolded by postgraduate students and/or academics in the humanities, engineering students could be introduced to discourse analysis to explore issues of power in interview transcripts; such discussions could lead to overt instruction about language and heightened awareness of effectively communicating to audiences. Drawing on interactive resources from private industry (see for example, Ourston Roundabout Engineering, 2003-2010), students could develop educational resources incorporating audio, spatial, linguistic and visual design with virtual reality simulation for drivers and pedestrians navigating roundabouts. As transformed practice, these resources could be modelled in local educational institutions to scaffold secondary or primary school students. Engineering lecturers could also 
promote online learning techniques such as wikis, aiming for collaborative reflection (see Smith, Mills, \& Myers, 2009). Building on praxis, these techniques could be incorporated into assessment to develop critical awareness about ethical dilemmas which engineers face and how these situations might compare to those of other professionals.

\section{CONCLUDING REMARKS}

Aiming to contribute to the discussion of developing professional engineers who possess highly proficient technical skills and seek social justice through reflective practice, this paper proposes new literacies for engineering students. Inspired by humanities-based theories and empirical studies in science education and engineering, the paper proposes new literacies for social justice and engineering. These literacies are represented by an emerging model which integrates recent work surrounding liberative pedagogy in engineering education (Baillie, 2006-2009; Catalano, 2006; Kabo, 2010; Riley, 2003) and a pedagogy of multiliteracies (New London Group, 1996, 2000).

Far from offering an all-encompassing solution to meet the curricular and pedagogical requirements of undergraduate engineering programs and professional accreditation standards, this model tentatively explores a holistic approach integrating elements of design, multimodal texts, authentic learning and critical thinking. The nucleus of the model lies in Freire's (1970) notion of praxis, viewed as an iterative process in which engineering students seek harmony between design, technical problem-solving, and commitment to humanity. Like Freire (2005), advocating for social justice in engineering education will always be fraught with tensions, dilemmas and struggles of power. But these efforts for a fairer and more just world must be sustained through innovation borne of reflective practice.

\section{REFERENCES}

Adams, M., Bell, L., \& Griffin, P. (2007). Teaching for diversity and social justice (Vol. 1). New York, NY: Routledge, Taylor and Francis Group.

Aikenhead, G. (2003). Review of research on humanistic perspectives in science curricula. Paper presented at the European Science Education Research Association (ESERA) 2003 Conference, Noordwijkerhout, The Netherlands (Aug. 19-23, 2003).

Americans with Disabilities Act of 1990, As Amended, 42 U.S.C. § 12101 et seq. (2008). Retrieved from http://www.ada.gov/pubs/ada.htm

Apelian, D. (2012). Engineers: Leaders, innovators, and builders. In G. Tryggvason \& D. Apelian (Eds.), Shaping our world. Engineering education for the 21st century (pp. 27-37). Hoboken, NJ: John Wiley \& Sons.

Archer, A. (2008). 'The place is suffering': Enabling dialogue between students' discourses and academic conventions in literacy. English for Specific Purposes 27(3), 255-266.

Arnold, L. S., Flannery, A., Ledbetter, L., Bills, T., Jones, M., Ragland, D., \& Spautz, L. (2010). Identifying factors that determine bicycle and pedestrian-involved collision rates that affect bicycle and pedestrian demand at multi-lane roundabouts. Berkeley, CA: University of California. Retrieved from http://www.path.berkeley.edu/PATH/Publications/PDF/PRR/2010/PRR-2010-34.pdf

Baillie, C. (2006). Engineers within a local and global society. San Rafael, CA: Morgan \& Claypool. doi:10.2200/S00059ED1V01Y200609ETS002

Baillie, C. (Ed.). (2006-2009). Synthesis lectures on engineers, technology and society [Series]. San Rafael, CA: Morgan \& Claypool. Retrieved from http://www.morganclaypool.com/toc/ets/1/1

Baillie, C., \& Catalano, G. (2009). Engineering and society: Working towards social justice, part 1. San Rafael, CA: Morgan \& Claypool. doi:10.2200/S00136ED1V01Y200905ETS008

Bell, D. (1993). Communitarianism and its critics. Oxford, UK: Clarendon Press. 
Bomer, R., Zoch, M. P., David, A., \& Hyounjin, O. (2010). New literacies in the material world. Language Arts 88(1), 9-20.

Borsheim, C., Merritt, K., \& Reed, D. (2008). Beyond technology for technology's sake: Advancing multiliteracies in the twenty-first century. The Clearing House: A Journal of Educational Strategies, Issues and Ideas 82(2), 87-90.

Bourdieu, P. (1991). Language and symbolic power (J. Thompson, Ed., G. Raymond \& M. Adamson, Trans.). Cambridge, MA: Polity Press.

Bourn, D., \& Neal, I. (2008). The global engineer: Incorporating global skills with UK higher education of engineers. London, UK: Department for International Development. Retrieved from http://eprints.ioe.ac.uk/839/1/Bourn2008Engineers.pdf

Brown, I. M., Lockyer, L., \& Caputi, P. (2010). Multiliteracies and assessment practice. In R. Cole \& D. Pullen (Eds.), Multiliteracies in motion (pp. 191-206). New York, NY: Routledge.

Catalano, G. (2006). Engineering ethics: Peace, justice and the earth. San Rafael, CA: Morgan \& Claypool. doi:10.2200/S00039ED1V01Y200606ETS001

Cole, D., \& Pullen, D. (2010). Introduction to multiliteracies in motion. Current theory and practice. In D. Cole \& D. Pullen (Eds.), Multiliteracies in motion. Current theory and practice (pp. 1-14). New York, NY: Routledge.

Coller, B. (2007). Implementing a video game to teach principles of mechanical engineering (AC 2007-1548). ASEE Annual Conference and Exposition, Conference Proceedings.

Coller, B. \& Scott, M. (2009). Effectiveness of using a video game to teach a course in mechanical engineering. Computers and Education 53(3), 900-912.

Commonwealth of Australia (2006). Mine rehabilitation: Leading practices sustainable development program for the mining industry. Canberra, ACT, Australia: Department of Industry, Tourism and Resources. Retrieved from MineRehabilitationHandbook.pdf http://www.ret.gov.au/resources/Documents/LPSDP/LPSDP-

Cooper, J., \& McKenna, J. (2008). Social justice in coastal erosion management: The temporal and spatial dimensions. Geoforum 39(1), 294-306.

Cumming-Potvin, W. (2009). Social justice, pedagogy and multiliteracies. Developing communities of practice for teacher education. Australian Journal of Teacher Education 34(1), 82-99.

Cumming-Potvin, W., Baillie, C., \& Bowden, J. (in press). Engineering for social and environmental justice: Scaffolding knowledge during collaborative writing journeys. International Journal for Infonomics 6(1). Retrieved from http://www.infonomics-society.org/IJI/Published\%20papers.htm

Cumming-Potvin, W., Renshaw, P., \& van Kraayenoord, C. E. (2003). Scaffolding and bilingual shared reading experiences: Promoting primary school students' learning and development. Australian Journal of Language and Literacy 26(2), 54-68. Retrieved from http://researchrepository.murdoch.edu.au/5850/

Duderstadt, J. J. (2008). Engineering for a changing world: A roadmap to the future of engineering practice, research and education. Ann Arbor: University of Michigan.

Edmund Rice Centre (2000). Social justice: What is a fair thing? Just Comment 3(1). Retrieved from http://www.erc.org.au/just comments/1040190025.shtml

Engineers Australia. (2010). Australian engineering competency standards-stage 1: Competency standards for professional engineers. Sydney, Australia: Author.

Exley, B. (2008). The senses of scientific literacies in a middle year multiliteracies project. Australian Journal of Middle Schooling 8(1), 12-16.

Feldman, L., \& Feldman, J. (2000). Developing information literacy skills in freshmen engineering technology students. Paper presented at the 30th ASEE/IEEE Frontiers in Education Conference, Kansas City, MO, October 18-21. Retrieved from http://fie-conference.org/fie2000/papers/1382.pdf

Flexner, A. (1972). Medical education in the United States and Canada: A report to the Carnegie Foundation for the Advancement of Teaching (Bulletin No. 4). Boston, MA: D. B. Updike, The Merrymount Press. (Reprinted from 1910, New York, NY: Carnegie Foundation). Retrieved from the Carnegie Foundation 
website: $\quad$ http://www.carnegiefoundation.org/publications/medical-education-united-states-andcanada-bulletin-number-four-flexner-report-0

Fraser, N. (2001, May). Social justice in the knowledge society: Redistribution, recognition, and participation. Invited keynote lecture at conference on the 'Knowledge Society,' Berlin, Germany: Heinrich Böll Stiftung. Retrieved from http://www.wissensgesellschaft.org/themen/orientierung/socialjustice.pdf

Freire, P. (1970). Pedagogy of the oppressed. New York, NY: Herder and Herder.

Freire, P. (2005). Teachers as cultural workers. Cambridge, MA: Westview Press.

Furtado, G. (2004). Accommodating vulnerable road users in roundabout design. Surrey, BC, Canada: A McElhanney Consulting Services Ltd. Retrieved from http://ci.lexington.ma.us/planning/Hartwell/Ped\%20Safety\%20at\%20Roundabouts.pdf

Garland, A., Massoumi, M., \& Ruble, B. (2007). Introduction. In A. Garland, A. Massoumi, \& B. Ruble (Eds.), Global urban poverty: Setting the agenda (pp 1-10). Washington, DC: Woodrow Wilson International Centre for Scholars. Retrieved from http://www.wilsoncenter.org/publication/global-urban-povertysetting-the-agenda

Gee, J. (2003). What video games have to teach us about learning literacy. New York, NY: Palgrave MacMillan.

Harran, M. (2006). A critical ethnographic study of report writing as a literacy practice by automotive engineers (PhD thesis). Rhodes University, Grahamstown, South Africa. Retrieved from http://eprints.ru.ac.za/913/

Hill, C., \& Woodall, L. (1999, September). Developing information literacy skills in first year engineering students. In L. Luong (Ed.), Unfolding Landscapes in Engineering Education. 11th Australasian Conference on Engineering Education, Adelaide, (pp. 310-314).

Jones-Kavalier, B., \& Flannigan, S. (2006). Connecting the digital dots: Literacy of the 21st Century. EDUCAUSE Quarterly 29(2), 8-10.

Inman, V., \& Davis, G. (2007). Synthesis of literature relevant to roundabout signalization to provide pedestrian access. Washington, DC: U.S. Access Board. Retrieved from http://www.accessboard.gov/research/roundabouts-signals/report.htm

International Reading Association Board of Directors. (2009). New literacies and 21st century technologies (Position statement). Newark, DE: International Reading Association. Retrieved from http://www.reading.org/general/AboutIRA/PositionStatements/21stCenturyLiteracies.aspx

Jacquemart, G. (1998). Modern roundabout practice in the United States. National Cooperative Highway Research Program Synthesis of Highway Practice 264. Washington, DC: Transportation Research Board. Retrieved from http://trid.trb.org/view/1998/M/487395

Jawitz, J., \& Case, J. (2009). Communicating your findings in engineering education: The value of making your theoretical perspective explicit. European Journal of Engineering Education 34(2), 149-154.

Kabo, J. (2010). Seeing through the lens of social justice: A threshold for engineering (PhD thesis). Department of Chemical Engineering, Queen's University, Kingston, Ontario, Canada.

Kalantzis, M., \& Cope, B. (2005). Learning by design. Altona, Victoria, Australia: Common Ground Pubishing.

Kareiva, P., Watts, S., McDonald, R., \& Boucher, T. (2007). Domesticated nature: Shaping landscapes and ecosystems for human welfare. Science 316, 1866-1869.

Kemmis, S., Cole, P., \& Suggett, D. (2005). Orientations to curriculum. In E. Hatton (Ed.), Understanding teaching (2nd ed., pp. 139-146). South Melbourne, Victoria, Australia: Thomson.

King, R. (2008). Addressing the supply and quality of engineering graduates for the new century. Strawberry Hills, NSW: Carrick Institute for Learning and Teaching in Higher Education Ltd. Retrieved from http://www.olt.gov.au/system/files/resources/Grants DBIprojec engineeringquality project\%20report 25march08.pdf

Kolm, S.-C. (1996). Modern theories of justice. Cambridge, MA: MIT Press.

Layton, E. (1971). The revolt of the engineers: Social responsibility and the American engineering profession. Cleveland, OH: Press of Case Western Reserve University. 
Leu, D. J., McVerry, J. G., O’Byrne, W. I., Kiili, C., Zawilinski, L., Everett-Cacopardo, H., . . Forzani, E. (2011). The new literacies of online reading comprehension: Expanding the literacy and learning curriculum. Journal of Adolescent \& Adult Literacy 55(1), 5-14.

Luke, C. (2000). New literacies in teacher education. Journal of Adolescent \& Adult Literacy 43(5), 424-436.

Martino, W., \& Cumming-Potvin, W. (2011). “They didn't have out there gay parents-they just looked like normal regular parents": Investigating teachers' approaches to addressing same-sex parenting and nonnormative sexuality in the elementary school classroom. Curriculum Inquiry 41(4), 480-500.

Messer, D., Kelly, P., \& Poirier, J. (2005). Engineering information literacy and communication. In Proceedings of the Twelfth International Conference on Learning, Granada. Spain. Retrieved from http://eprints.qut.edu.au/1606/

Mills, K. (2009). Multiliteracies: Interrogating competing discourses. Language and Education 23(2), 103-116.

National Academy of Engineering, Committee on Public Understanding of Engineering Messages. (2008). Changing the conversation: Messages for improving public understanding of engineering. Washington, DC: National Academies Press. Retrieved from http://www.nap.edu/catalog.php?record id=12187

National Council of Teachers of English. (2008). 21st century curriculum and assessment framework (Position statement). Retrieved from http://www.ncte.org/positions/statements/21stcentframework

New London Group (1996). A pedagogy of multiliteracies: Designing social futures. Harvard Educational Review 66(1), 60-93. Retrieved from http://her.hepg.org/content/17370n67v22j160u/

New London Group (2000). A pedagogy of multiliteracies: Designing social futures. In B. Cope \& M. Kalantzis (Eds.), Multiliteracies: Literacy learning and the future design of social futures (pp 9-38). South Yarra, Australia: MacMillan.

Norris, S., \& Phillips, L. (2003). How literacy in its fundamental sense is central to scientific literacy. Science Education 87, 224-240.

Novak, M., (2000). Defining social justice. First Things First 108, 11-13.

Ourston Roundabout Engineering: Educational tools. (2003-2010). Retrieved from http://www.ourston.com/resources/educational-tools.html

Paavola, J., \& Adger, W. (2006). Fair adaption to climate change. Ecological Economics 56(3), 594-609.

Palmer, S., \& Tucker, B. (2004). Planning, delivery and evaluation of information literacy training for engineering and technology students. Australian Academic \& Research Libraries 35(1), 1-7.

Pilay, A. (2010). Embracing multiliteracy for teaching and learning in higher education. SAJHE 24(5), 771781.

Pool, R. (2003). How society shapes technology. In A. H. Teich (Ed.), Technology and the future (9th ed., pp. 13-22). Belmont, CA: Wadsworth/Thomson Learning.

Riley, D. (2003). Pedagogies of liberation in an engineering thermodynamics class. (AC 2003- 2692). ASEE Annual Conference and Exposition, Conference Proceedings.

Riley, D. (2008). Engineering and social justice. San Rafael, CA: Morgan \& Claypool. doi:10.2200/S00117ED1V01Y200805ETS007

Roberts, D. F., Foehr, U. G., \& Rideout, V. (2005). Generation m: Media in the lives of 8-18 year-olds (Technical report). Menlo Park, CA: Henry J. Kaiser Family Foundation. Retrieved from http://www.kff.org/entmedia/upload/Generation-M-Media-in-the-Lives-of-8-18-Year-olds-Report.pdf

Rodegerdts, L., Bansen, J., Tiesler, C., Knudsen, J., Myers, E., Johnson, M., ... O'Brien, A. (2010). Roundabouts: An informational guide (2nd ed.). National Cooperative Highway Research Program Report 672. Washington, DC: Transportation Research Board. Retrieved from http://onlinepubs.trb.org/onlinepubs/nchrp/nchrp rpt 672.pdf.

Roundabout. (n.d.). Oxford Dictionaries. Oxford, UK: Oxford University Press. Retrieved from http://oxforddictionaries.com/definition/english/roundabout?q=roundabout

Rountree, M. A., \& Pomeroy, E. C. (2010). Bridging the gaps among social justice, research and practice. Social Work 55(4), 293-295. 
Russell, E., \& Mandavilli, S. (2004). Can modern roundabouts safely accommodate all users? ITE Annual Meeting and Exhibition, Proceedings. Washington, DC: Institute of Transportation Engineers. Retrieved from http://www.mtjengineering.com/uploads/assets/pdf/83ee5721e9845f6f6e25d6552c99f355563f0d56.p $\underline{\mathrm{df}}$

Shaffer, D. W. (2006). How computer games help children learn. New York, NY: Palgrave Macmillan.

Sheppard, S. D., Macatangay, K., Colby, A., \& Sullivan, W. M. (2008). Educating engineers: Designing the future of the field. San Francisco: Jossey-Bass.

Singer, C., Williams, T., \& Raper, R. (1954-84). A history of technology. Vol. 3. From the renaissance to the industrial revolution. Oxford, UK: Clarendon Press.

Smith, E., Mills, J., \& Myers, B. (2009). Online learning techniques: Using wikis and blogs for assessment in first year engineering. Interactive Collaborative Learning Conference, Proceedings, Villach, Austria. Retrieved from http://www.ojs.unisa.edu.au/index.php/atna/article/view/378/288

Snyder, I. (2008). The literacy wars. Why teaching children to read and write is a battleground in Australia. Crows Nest, NSW: Allen \& Unwin.

Spires, H., Lee, J., \& Lester, J. (2008). The connection between 21st century skills and game-based learning. Meridian. A Middle School Computer Technologies Journal 1(11), 1-4.

Strutz, M., Orr, M., \& Ohland, M. (2012). Low socioeconomic status individuals: An invisible minority in engineering. In C. Baillie, A. Pawley, \& D. Riley (Eds.), Engineering and social justice in the university and beyond (pp. 142-156). West Lafayette, IN: Purdue University Press.

Transportation Research Board (2013). Guidelines for the Application of Crossing Solutions at Roundabouts and Channelized Turn Lanes to Assist Pedestrians with Vision Disabilities NCHRP 03-78B [Pending] http://apps.trb.org/cmsfeed/trbnetprojectdisplay.asp?projectid=3389

U.S. Access Board. (2010). Pedestrian access to modern roundabouts: Design and operational issues for pedestrians who are blind. Washington, DC: Author. Retrieved from http://www.accessboard.gov/research/roundabouts/bulletin.htm

U.S. Environmental Protection Agency. (2011). Environmental justice: Frequently asked questions. Retrieved from http://www.epa.gov/environmentaljustice/resources/faqs/

Vygotsky, L. S. (1978). Mind in society: The development of higher psychological process. Cambridge, MA: Harvard University Press.

Walsh, M. (2008). Worlds have collided and modes have merged: Classroom evidence of changed literacy practice. Literacy 42(2), 101-108.

Wankat, P., Felder, R., Smith, K., \& Oreovicz, F., (2002). The scholarship of teaching and learning in engineering. In M. T. Huber and S. Morreale (Eds.), Disciplinary styles in the scholarship of teaching and learning: Exploring common ground (217-238). Menlo Park, CA: Carnegie Foundation for the Advancement of Teaching.

Warhurst, J., Grundy, S., Laird, D., \& Maxwell, T. (2005). Curriculum development. In E. Hatton (Ed.), Understanding teaching (2nd ed., pp. 169-182). South Melbourne, Victoria, Australia: Thomson.

Weinstein, M. (2006). Slash writers and guinea pigs and models for a scientific multiliteracy. Educational Philosophy and Theory 38(5), 607-623.

Young, I. M. (2000). Five faces of oppression. In M. Adams, X. Zuniga, C. R. Castaneda, M. L. Peters, H. W. Hackman, \& W. J. Blumenfeld (Eds.), Readings for diversity and social justice (pp. 35-49). New York, NY: Routledge. 